\title{
Editorial
}

\section{Seção de revisão e atualização}

Não se faz ciência de qualidade, sem que haja, dentro de cada tema, um constante exercício de integração e sistematização crítica sobre o conjunto de resultados acumulados até então. Isto passa necessariamente pela revisão rigorosa da base conceitual, metodológica e de dados utilizada para se chegar a estes resultados.

A importância deste exercício de sistematização e revisão é ainda mais fundamental quando se trata de áreas interdisciplinares, como é o caso das geociências ambientais e do Quaternário. Nestas áreas, a multiplicação de trabalhos com foco em apenas uma especialidade, ou em apenas uma linha interpretativa, pode ter, como pior consequência, o aparecimento de um mosaico de modelos parciais, incapazes de dialogar entre si. Uma torre de Babel científica. Ou a "barbárie da especialização”, nos termos de Ortega y Gasset. E artigos de revisão, integração e atualização passam, portanto, a ter papel epistemológico fundamental.

Está lançada a pedra inaugural, e que venham mais artigos de revisão e atualização sobre o Quaternário brasileiro!

Paulo C. F. Giannini 